\title{
DISTURBANCE ECOLOGY OF TASMANIAN HIGHLAND GRASSLAND - AN OVERVIEW AND IMPLICATIONS FOR CONSERVATION MANAGEMENT
}

\author{
by Steven W. J. Leonard and Denna Kingdom
}

(with two text-figures, one plate and one appendix)

\begin{abstract}
Leonard, S.W.J. \& Kingdom, D. 2017 (6:xii): Disturbance ecology of Tasmanian highland grassland — an overview and implications for conservation management. Papers and Proceedings of the Royal Society of Tasmania 151: 1-10. https://doi.org/10.26749/rstpp.151.1 ISSN 0080-4703. Department of Ecology, Environment and Evolution, La Trobe University, Bundoora, Victoria, 3086 Australia (SWJL*), Tasmanian Land Conservancy, Lower Sandy Bay, Tasmania, 7005 Australia (DK). *Author for correspondence. Email: s.leonard@latrobe.edu.au
\end{abstract}

Active manipulation of disturbances such as fire and grazing is often necessary to maintain or enhance biodiversity values in grasslands. However in many instances information is lacking on the disturbance regimes most likely to achieve conservation aims. This paper provides an overview of the effects of fire and grazing in Tasmanian highland grasslands, and the implications of these for conservation management of this vegetation. In Tasmania, highland grassland is defined as occurring above $600 \mathrm{~m}$ above sea level. The vegetation is typically dominated by species of Poa. Highland grassland is grazed by a suite of native herbivores and has a history of stock grazing, which continues at some sites of high biodiversity value. There is evidence that Indigenous Tasmanians regularly burnt highland grasslands and that Indigenous burning was instrumental in maintaining grassland at sites that otherwise would be forest. For highland grasslands below 1000 $\mathrm{m}$ asl, a reduction in the biomass of dominant grasses through disturbance is necessary in order to maintain plant species diversity. The use of periodic fire, together with native grazing, is likely to be beneficial in this regard. The combination of fire and grazing is also likely to prevent woody plant invasion and maintain vegetation structural heterogeneity. The near ubiquity of native grazing species means there is no ecological imperative for stock grazing. Low productivity of grasslands occurring above $1000 \mathrm{~m}$ means that competitive exclusion of interstitial species by grasses is unlikely and therefore active application of disturbance as a management tool will rarely, if ever be necessary. Disturbance management should be accompanied by a well-designed monitoring program and regular review of the management strategy. Key Words: herbivory, fire regimes, alpine, sub-alpine, vegetation management, Poa, grasslands.

\section{INTRODUCTION}

Natural grasslands have been heavily transformed by human activity (Henwood 2010). Apart from conversion to introduced pastures, crops or urban settlements, a major factor in this transformation is alteration in disturbance regimes (Schnoor et al. 2015). Disturbance regimes are a critical determinant of grassland structure and composition (Belsky 1992, Tremont \& McIntyre 1994, Leonard \& Kirkpatrick 2004). Where grasslands are managed for conservation, active manipulation of disturbances such as fire and grazing is often necessary to maintain or enhance biodiversity values (Kirkpatrick et al. 2005). However, in many instances information is lacking on the disturbance regimes most likely to achieve conservation aims. A particularly contentious issue is the use of livestock grazing as a tool for achieving biodiversity conservation goals (Kirkpatrick et al. 2005, Lunt et al. 2007). While several studies have indicated that livestock grazing can promote biodiversity values (e.g., Gilfedder \& Kirkpatrick 1994, Leonard et al. 2004), its effects are contingent on a range of factors such as vegetation composition, landscape context and site history (Lunt et al. 2007). Interactions of livestock grazing with other disturbances, in particular fire, also need to be considered (Fuhlendorf et al. 2008).

This paper addresses these issues in the context of highland grasslands in Tasmania, Australia. We define grassland as vegetation with $<5 \%$ tree cover, and in which the tallest vegetation stratum with a cover of more than $10 \%$ is dominated by grasses or herbs. In Tasmania, highland grassland is defined as (usually) Poa-dominated grassland occurring above $600 \mathrm{~m}$ asl (the upper limit of Themeda triandra Forsk. in Tasmania), including grasslands occurring in the alpine (sensu Kirkpatrick 1983) zone (Kirkpatrick \& Duncan 1987); see below for detailed description of the vegetation. These grasslands are also referred to as "montane grasslands" in some sources e.g., Bowman et al. (2013). This definition of highland grassland largely equates to that of the TASVEG community "Highland Poa grassland" (Kitchener \& Harris 2013). While the focus of this paper is on grassland so defined, we recognise that highland grassland has floristic affinities and often co-occurs with grassy woodland, shrubland and sedgeland, and therefore some of the discussion may also be relevant to these communities.

There is currently approximately 26000 ha of highland grassland in Tasmania (TVMMP 2013), comprising a significant proportion of remaining native grassland in temperate Australia (Balmer et al. 2004). No precise estimate is available as to what proportion of the preEuropean invasion extent of highland grassland its current extent represents. However Kirkpatrick (1999) stated that about $60 \%$ of the pre-European extent of Tasmanian grassland overall remains, and that most of this occurs above $600 \mathrm{~m}$. Highland grasslands in good condition have high biodiversity value, being floristically rich and often supporting threatened flora and fauna species (Kirkpatrick 1991). While 68\% of highland grassland occurs within secure public and private reserves (DPIPWE 2016), some important examples are unreserved. Unreserved highland grasslands are subject to a range of threats, including outright loss through inundation or 
conversion to exotic pasture or tree plantations. However even those within the reserve system may be reduced in extent or quality due to inappropriate disturbance regimes (e.g., Kirkpatrick \& Balmer 1991, Bowman et al. 2013). Therefore understanding the effects of disturbance, and the disturbance regimes most conducive to maintaining biodiversity values, is crucial for effective conservation management of this vegetation.

We provide an overview of the effects of fire and grazing in Tasmanian highland grasslands, and their implications for conservation management. Our paper builds upon previous reviews that have included highland grassland in discussion of the ecology of Tasmanian grassy vegetation generally (Kirkpatrick et al. 1988, Kirkpatrick 1991, 1999). In addition to focusing specifically on the highland portion of Tasmanian grassland, we also synthesise more recent research with that included in previous reviews. While our paper does not take the form of a systematic literature review, we have endeavoured to be comprehensive in our inclusion of relevant literature (focusing on peer-reviewed journal papers), in particular that published since 1999 (when the last review of Tasmanian grassy vegetation was published; the results of a systematic review of this more recent literature are included in appendix 1).

\section{VEGETATION DESCRIPTION AND ENVIRONMENTAL RELATIONSHIPS}

Highland grasslands are typically dominated by one or more species of Poa (in particular P. gunnii Vickery and $P$. labillardierei Steud.), which may occur as a short or long $(\sim 10-100 \mathrm{~cm})$ dense sward or as more isolated tussocks amidst forb-rich lawn (pl. 1). Heavily grazed areas may be dominated by Rytidosperma nudiflorum (P. Morris) Connor \& Edgar. Grasslands in good condition exhibit a diverse array of forbs, with Asteraceae spp., Velleia montana Hook.f., Ranunculus spp., Viola spp. and Geranium
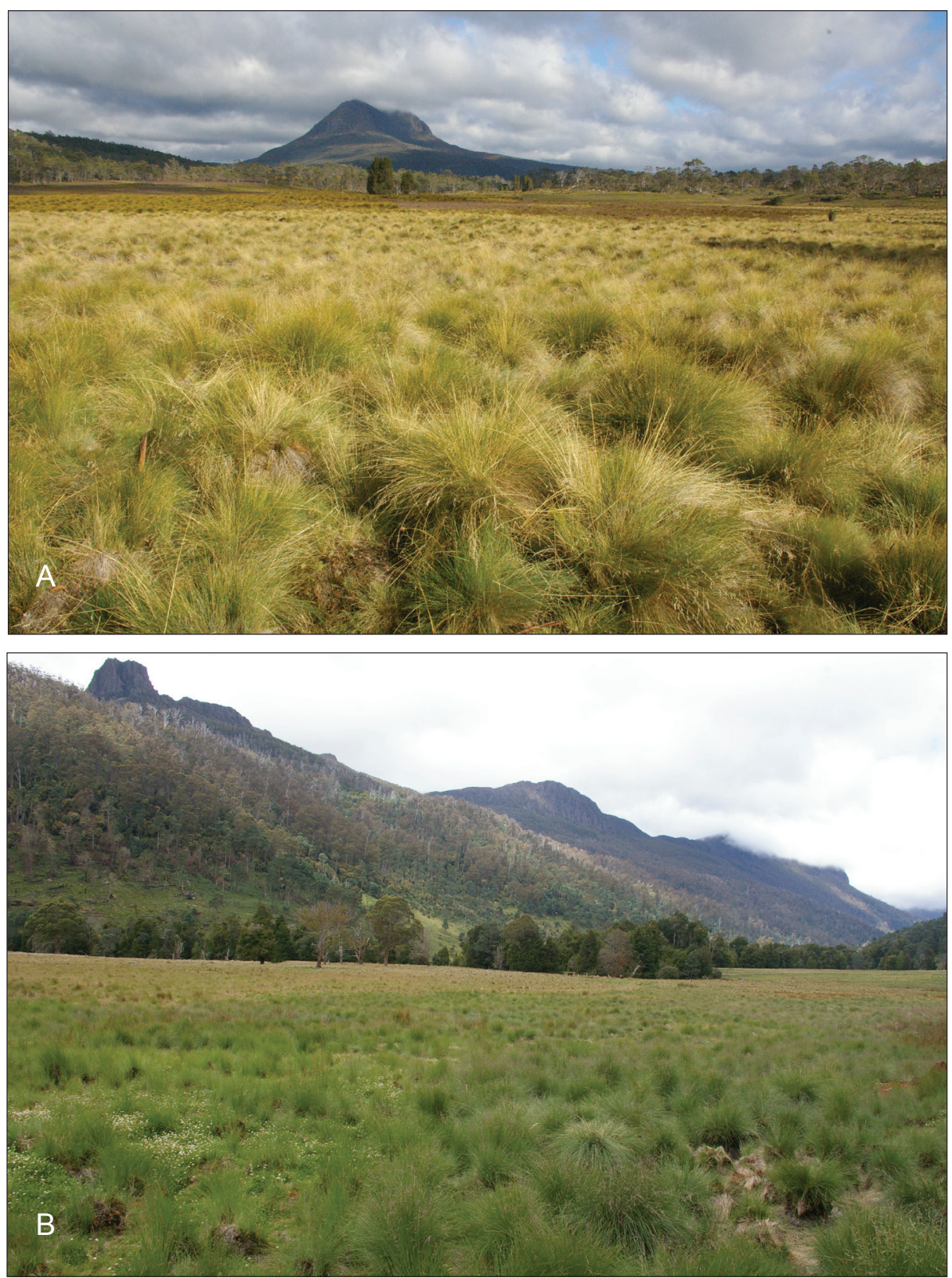

PLATE 1 - Examples of Tasmanian highland grasslands. A: long unburnt grassland exhibiting dense Poa tussocks and low abundance of interstitial species. B: Regularly burnt grassland. The area in the foreground has been burnt 1-2 years previously. Note space between Poa tussocks and abundance of forbs. The yellowish grassland patch in the left mid-ground has remained unburnt for longer. 
spp. being common constituents. Emergent shrubs are also usually present, including Epacris gunnii Hook.f., Acrothamnus hookeri (Sond.) Quinn, A. montanus (R.Br.) Quinn, Olearia algida N.A. Wakef. and Richea acerosa (Lindl.) F.Muell. Scattered taller shrubs may also occur, such as Hakea macrocarpa R.Br., Richea scoparia Hook.f., Coprosma nitida Hook.f and Tasmannia lanceolate (Poir.) A.C.Sm. With increasing waterlogging, monocots such as Empodisma minus (Hook.f.) L.A.S.Johnson \& D.F.Cutler, Baloskion austral (R.Br.) B.G.Briggs \& L.A.S.Johnson and Lepidosperma filiforme Labill. become more prominent, and grassland grades into sedgeland or rushland. There is usually a sharp boundary between grasslands and adjoining forest or woodland (Fensham \& Kirkpatrick 1992).

The most extensive areas of highland grassland occur on the Central Plateau, with outlying occurrences in the northwest and smaller, more isolated pockets in the northeast (Kirkpatrick 1999; fig. 1). These grasslands occur on relatively fertile, well-drained soils derived from dolerite, basalt, carbonate rocks and alluvium, although grassland on siltstone-derived soils occur in snow patches in the Cradle Mountain area and at the Walls of Jerusalem (Parry et al 2016). Kirkpatrick \& Duncan (1987) identified six distinct highland grassland communities. The distribution of these communities was related to variation in soil fertility, summer temperature, drainage and precipitation. In addition, highland grasslands exhibit lower productivity at higher altitudes, due to lower temperatures and associated effects including frost heave, such that grasslands above $-1000 \mathrm{~m}$ asl take much longer to recover from disturbance than those below (i.e., decades cf. years; Gibson \& Kirkpatrick 1989, Bridle et al. 2001, Kirkpatrick \& Bridle 2013).

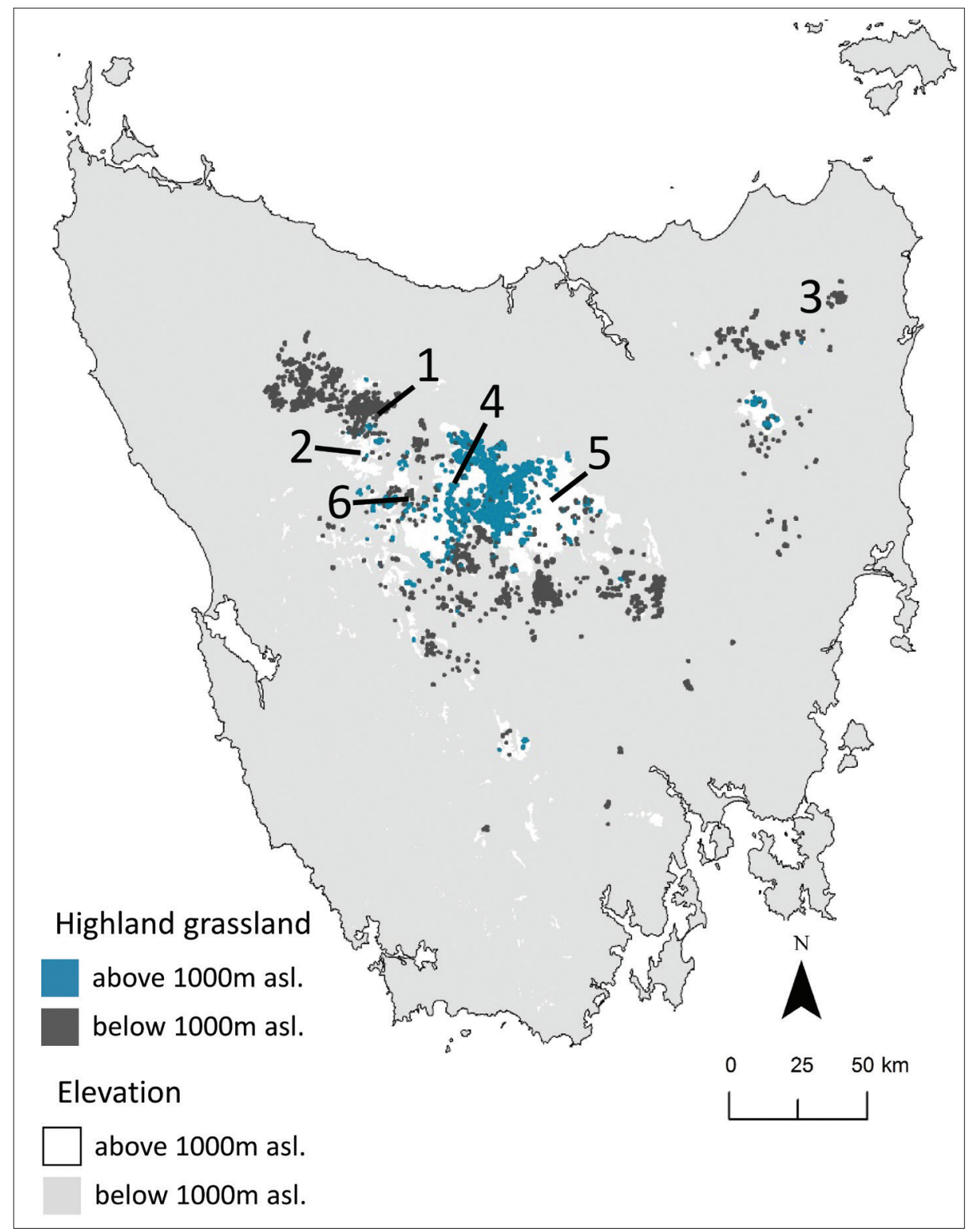

FIG. 1 - Distribution of highland grassland in Tasmania, and locations mentioned in text. $1=$ Vale of Belvoir, $2=$ Cradle Valley, $3=$ Paradise Plains, 4 = Walls of Jerusalem, $5=$ Central Plateau, $6=$ Lee's Paddocks. Data sources: Land Tasmania (2007), TVMMP (2013). 


\section{DISTURBANCE ECOLOGY OF GRASSLANDS}

\section{General patterns}

Grubb (1986) examined the mechanisms allowing the persistence of sparsely and patchily distributed species in English chalk grasslands. He proposed a model for this system in which most species remain relatively rare due to competition from the dominant perennial grasses, while defoliation of these grasses through disturbances such as fire and grazing produce niches in which less competitive species can persist. Grubb's model has been demonstrated to be widely applicable to grassland system dynamics. Grasslands subject to moderate disturbance exhibit higher species richness than those that are undisturbed (e.g., Stuwe \& Parsons 1977, Fensham \& Kirkpatrick 1989). However, where disturbance is frequent and/or intense, the resultant stress on plants may outweigh the benefits of reduced competition, resulting in a decline in both the dominant grasses and interstitial species (McIntyre \& Lavorel 1994). In these circumstances weedy (often exotic) colonising species are promoted and species richness is reduced. The fact that grassland species richness is maximised at an intermediate point on a continuum between no disturbance and severe disturbance appears to be in accord with the intermediate disturbance hypothesis (Connell 1978). However the level of disturbance that promotes species richness is contingent on a number of factors, including productivity and evolutionary history, and therefore varies across systems (Milchunas et al. 1988).

Most natural grasslands are subject to grazing by wild and/or domestic animals. Many grasslands also experience periodic natural or anthropogenic fire. These disturbances are similar in that they remove vegetation biomass (Bond 2005) and therefore may promote species richness. For this reason conservation managers often apply one or other (or both) of these disturbances to grasslands. However fire and grazing differ in a number of ways, which means they may produce distinct vegetation outcomes (Lunt 1997a,b, Kirkpatrick et al. 2005). The key difference between fire and grazing as disturbances is in selectivity of biomass removed (Bond 2005). Fire is unselective, consuming all sufficiently dry vegetation that it encounters. In contrast, grazing animals will preferentially consume some elements of the vegetation over others. The degree of selectivity and the species selected vary amongst grazing species. For example, sheep preferentially target forbs (Leigh \& Holgate 1978), while Eastern Grey Kangaroos (Macropus giganteus Shaw, 1790) feed mostly on grasses (Lunt 1991). For bulk feeders, such as cattle, feeding preference is based more on the vertical stature of plants, rather than species; i.e., the preference is for taller more accessible foliage over shorter plants (Noy-Meir et al. 1989). Other effects of grazers, such as trampling (Ferguson et al. 2010) and nutrient cycling and redistribution in the form of dung and urine (McNaughton 1984) can also be ecologically important.

A striking example of the potential for variation in the type of disturbance to shape grassy vegetation was provided by Lunt (1997a). In this study, the original grassy forest vegetation of the Gippsland Plain was found to have segregated under different disturbance regimes into grassland, associated with frequent burning and no grazing, and remnant grassy forest, which was lightly grazed by stock, with these "new" communities containing different subsets of the original flora. A major difference between these derived vegetation types was a preponderance of tall forbs in the burnt, ungrazed grassland remnants (Lunt 1997b). Similarly, different grazing species may also result in different outcomes in the vegetation. For example, Bridle \& Kirkpatrick (1999) found that grassland on the Central Plateau subject to sheep grazing differed in structure and composition from that grazed by rabbits and Bennett's Wallabies (Macropus rufogriseus (Desmarest, 1817)).

The interactive effects of fire and grazing can be profound, as well as being difficult to predict by considering either disturbance in isolation (Fuhlendorf et al. 2010, Kirkpatrick et al. 2011). A well-known interaction of fire and grazing is the movement of grazers to regenerating recently burnt areas in order to consume nutritious "green pick", a phenomenon that has been widely exploited by hunters and pastoralists (Cubit 1996, Murphy \& Bowman 2007). In South African savanna, the "magnet effect" of recently-burnt grassland was found to result in high grazing intensity and maintenance of grazing lawns when the burnt area was relatively small (Archibald \& Bond 2004). When fires were large, grazing animals were more dispersed and therefore grazing intensity at any one point was reduced. Where grazers are strongly attracted to recently burnt areas the intense grazing and subsequent abandonment of patches can result in a shifting mosaic of vegetation states (Fuhlendorf \& Engle 2004). The ecological heterogeneity brought about by this pattern of disturbance can be important in maintaining biodiversity (Fuhlendorf et al. 2008). However the strength of the "magnet effect" can vary depending on factors such as the relative palatability and landscape context of burnt and unburnt vegetation (Kirkpatrick et al. 2011, Styger et al. 2011).

While fire can influence patterns of grazing, the converse is also true. Where grazing intensity is sufficient to form grazing lawns, fuel loads may be maintained at such low levels that fire is rarely possible (Leonard et al. 2010). However, in grasslands dominated by unpalatable tussock grasses, selective grazing of comparatively palatable new growth can elevate dead fuel levels and therefore increase the likelihood of fire. When fire occurs in such systems, intensive post-fire grazing can cause grassland to shift from the unpalatable and flammable tussock state to the palatable, rarely burnable lawn state (Kirkpatrick et al. 2011 , 2016). Conversely, a decrease in grazing intensity, for example due to population decline in grazers in response to disease, predation or other factors, could lead to a vegetation transition in the opposite direction.

Fire and grazing may have synergistic effects on grassland vegetation. For example, in North American prairie, plant species richness was found to be higher in grassland where fire and grazing co-occurred compared to grassland subject to either disturbance alone (Collins \& Barber 1985). 
The combination of fire and grazing may be effective in preventing tree or shrub invasion of grassland where either disturbance alone would not have this effect (Kirkpatrick 2004). An example of the potential negative consequences of the combination of fire and grazing is the Central Plateau, where frequent burning and overgrazing by sheep resulted in severe sheet erosion and the transformation of grassland into shrubland (Jackson 1973, Kirkpatrick \& Duncan 1987).

\section{DISTURBANCE IN TASMANIAN HIGHLAND GRASSLANDS}

\section{Grazing}

Grazing and fire are the major disturbances in Tasmanian highland grasslands. Grazing by Bennett's Wallabies, Common Wombats (Vombatus ursinus Shaw, 1800) and (below $1000 \mathrm{~m}$ ) Tasmanian Pademelons (Thylogale billardierii Desmarest, 1822) is essentially ubiquitous in this vegetation. At some sites these species occur at high densities and remove considerable amounts of vegetation biomass (Leonard et al. 2010). Rabbits also occur in most grasslands. In addition, some areas are seasonally grazed by domestic stock, mainly cattle. Cattle and sheep grazing in highland grasslands was common in the nineteenth and twentieth centuries (Shepherd 1973). Highland sheep grazing largely ended when the Tasmanian Wilderness World Heritage Area was extended to include the eastern Central Plateau in 1989 (Kirkpatrick 2007). Cattle grazing has also gradually declined, but is still practised in a number of locations, including grasslands with high conservation value (e.g., Vale of Belvoir, Lees Paddocks). Bridle \& Kirkpatrick (1999) found that sheep had greater impacts on the vegetation than rabbits and native herbivores. Where cattle are grazed at low density, they appear not to have severe negative effects on grassland vegetation, but do negatively affect associated wetland areas through pugging and erosion (Tengia et al. 2016).

In the absence of grazing, highland grasslands below $1000 \mathrm{~m}$ asl conform to the generally observed pattern of increasing dominance by tussock-forming grasses, with a concomitant decline in species richness as smaller-statured species are outcompeted (Gibson \& Kirkpatrick 1989). However, this process may be less pronounced than in other grassy systems, such as lowland Themeda grasslands, due to the relative unpalatability of Poa (Leonard et al. 2010). In addition, a number of palatable native (e.g., Microseris lanceolata (Walp.) Sch.Bip., Craspedia spp.) and exotic (e.g., Hypochaeris radicata L.) taxa, and tall forbs generally, occur more frequently when grazing is removed (Bridle $\&$ Kirkpatrick 1999). Many of these species also produce more flowers in the absence of grazing, and therefore their reduced occurrence in grazed grassland may be a result of both direct predation and indirect effects on reproductive success (Bridle \& Kirkpatrick 2001). Grazing also reduces shrub cover (Gibson \& Kirkpatrick 1989) and eucalypt seedling establishment (Fensham \& Kirkpatrick 1992) and so may be important in preventing a transition to shrubland or woodland (Kirkpatrick et al. 2016).

The maintenance of inter-tussock spaces and the creation of bare ground by grazers provides regeneration niches for a number of highland grassland forb species, including the nationally endangered Leucochrysum albicans albicans (A.Cunn.) Paul G.Wilson (Gilfedder \& Kirkpatrick 1994). However overgrazing by stock (combined with fire) produced severe sheet erosion and a transition to shrubland on the Central Plateau (Jackson 1973, Kirkpatrick \& Duncan 1987). These negative impacts of grazing are most pronounced in grasslands above $1000 \mathrm{~m}$, where vegetation recovery from disturbance is extremely slow (Gibson \& Kirkpatrick 1989, Bridle et al. 2001, Kirkpatrick \& Bridle 2013). This slow recovery and associated soil erosion is exacerbated by frost heave in soils exposed by vegetation removal, which in turn is most severe in areas of relatively low rainfall (e.g., eastern Central Plateau), due to shorter periods of snow lie (Cullen 1995).

\section{Fire}

Historical and archaeological sources indicate that burning by Tasmanian Aboriginal peoples has been a key driver of vegetation patterns (Moss et al. 2007, Fletcher \& Thomas 2010). There is considerable evidence that in western Tasmania, Aboriginal burning was instrumental in the maintenance of buttongrass moorland in areas climatically capable of supporting rainforest (Jackson 1968, di Folco \& Kirkpatrick 2013). Similarly, analysis of fire scars on Athrotaxis cupressoides D.Don on the Central Plateau indicates that Indigenous Tasmanians applied patchy, low intensity fire to grassy vegetation in this area, with the fire return interval estimated to be 22-24 years (Holz et al. 2015). In addition, there is evidence that Indigenous burning was instrumental in maintaining the treelessness of highland grasslands occurring within a forest matrix. In the case of Paradise Plains, a grassland surrounded by rainforest in northeastern Tasmania, the presence of burnt Nothofagus logs dating from the pre-European era suggests that Aboriginal burning extended, if not created, this grassland (Ellis 1985). Similarly, the invasion of grasslands by firesensitive shrubs in the period since European colonisation also suggests the role of Aboriginal burning in previously excluding woody species (Bowman et al. 2012). Where the main woody invader is the serotinous obligate seeder Leptospermum lanigerum (Sol. ex Aiton) Sm., it can be inferred that such burning occurred at intervals less than the eight years it takes this species to reach reproductive maturity (Wood et al. 2017).

However burning alone cannot account for the exclusion of fire-tolerant sclerophyllous species from grassland, where these species are present nearby (Fensham \& Fairfax 2006). Fensham \& Kirkpatrick (1992) found that competitive exclusion by grasses was key factor in preventing woody invasion of highland grasslands. Soils may also play a role in causing treelessness. Lunt (1997c) found that the distribution of grassland on the Gippsland plain in Victoria closely matched that of flat plains with clay loam 
soils, and ascribed the absence of trees from these areas to the combined effects of winter waterlogging and summer drought. In Tasmania, where vegetation and geological boundaries are closely congruent (such as the Vale of Belvoir), the occurrence of grasslands may similarly be a product of soil properties. Soil properties may also play a role in feedbacks between plant growth rates and fire regimes, which in turn influence grassland/forest boundary dynamics (Wood et al. 2017).

Graziers and hunters have used fire to manage highland grasslands since the 1820s, and it is possible that their practices were learnt from Indigenous Tasmanians (Cubit 1996, Holz et al. 2014). The aim of burning in the high country was to produce palatable feed for stock and game (Kirkpatrick \& Bridle 2013). Fires were generally lit in early spring (when highland grassland has a high proportion of frost-killed dead foliage and is most flammable (Leonard 2009) such that fresh growth was produced in the following summer. In the more productive grasslands below 1000 $\mathrm{m}$, patches were burnt rotationally with a typical inter-fire interval of 2-4 years (Cubit 1996, Wood et al. 2016). Examination of areas burnt recently by graziers indicate that these fires result in fine-grained patchiness of burn severity, including the occurrence of unburnt patches, reflecting variation in fuel curing and load (S. Leonard pers. obs.).

Tasmanian highland grasslands below $1000 \mathrm{~m}$ asl exhibit the general pattern of grass biomass removal by fire facilitating the persistence of interstitial species (Ferguson et al. 2009, Kirkpatrick et al. 2016). Kirkpatrick \& Balmer (1991) suggested that the prolonged absence of fire from grassland at Cradle Valley resulted in a decline in forb abundance. The removal of fire from highland grasslands may also lead to the accumulation of peat, which in turn may facilitate a transition to sedgeland (Kirkpatrick 1991). Bare ground created by fire may provide niches for woody plant establishment (Fensham \& Kirkpatrick 1992). In the absence of grazing this would result in succession to shrubland or woodland (Kirkpatrick 2004), however this is unlikely in almost all Tasmanian highland grassland, which is grazed by native animals. Conversely, the unpalatable shrub Richea acerosa can come to dominate grassy vegetation when fire is absent and grazing pressure relatively high (Kirkpatrick \& Bridle 2016). However, as noted above, frequent firing and heavy grazing has led to shrub invasion on the Central Plateau. These observations highlight the complexity and unpredictability of responses that may arise due to changes in disturbance regimes in highland grasslands, particularly where disturbances interact (Kirkpatrick et al. 2011).

Grazing of highland grassland in the wake of fire may bring about a transition from a tussock-dominated structure to grazing lawn (Leonard et al. 2010, Kirkpatrick et al. 2011). It is possible that subsequent fires within a grassland will cause grazers to abandon existing lawns and concentrate on the newly burnt area, initiating the kind of shifting mosaic of grassland structure observed in North American prairie (Fuhlendorf \& Engle 2004). However, in contrast to the prairies, Tasmanian grasslands occur as relatively small patches within extensive tracts of less palatable vegetation. This means that they are likely to be foci for grazing whether they are recently burnt or not (Kirkpatrick et al. 2011), and so the potential for a grazing-induced mosaic to form may be limited. Nonetheless, a number of highland grasslands exhibit a mix patches with lawn or tussock structure (Leonard et al. 2010) and future research to determine the relationships of such structural heterogeneity to fire and grazing regimes would be beneficial.

\section{MANAGEMENT OF FIRE AND GRAZING IN TASMANIAN HIGHLAND GRASSLAND}

There is ample evidence that a reduction in the biomass of dominant grasses through disturbance is necessary in order to maintain plant species diversity in Tasmanian highland grassland below $1000 \mathrm{~m}$ asl, as well as to prevent succession towards shrubland/forest or sedgeland (fig. 2). Grazing provides this to some degree, however the relative unpalatability of Poa means that grazing is likely to be concentrated on interstitial species rather than grass tussocks (Leonard et al. 2010). The ineffectiveness of native grazing alone in reducing Poa biomass is illustrated by the dense grass sward and low forb abundance in grasslands with large populations of wombats and wallabies, but a prolonged absence of fire (e.g., Cradle Valley; Kirkpatrick \& Balmer 1991). Previous management-focused reviews have suggested that, in the absence of native grazers, stock grazing may be beneficial as a means of reducing grass biomass (Kirkpatrick 1991). However recent research has shown that low-density cattle grazing does not reduce tussock grass biomass in highland grassland (Leonard et al. 2010) and , while not having negative effects on grassland itself, does have negative effects on associated wetland areas through pugging and bank erosion (Tengia et al. 2016). Considering this, and the near ubiquity of native grazing, there would seem to be no ecological imperative for cattle grazing in highland grasslands.

The use of periodic fire is likely to be beneficial in managing highland grassland below $1000 \mathrm{~m}$ as it is an effective means of reducing Poa biomass (Kirkpatrick et al. 2011), creates regeneration niches for interstitial species and does not selectively consume these species (fig. 2.). Fire may also inhibit woody plant invasion (Bowman et al. 2013, Kirkpatrick \& Bridle 2015, Wood et al. 2016). The combination of fire and grazing is also likely to increase floristic diversity and structural heterogeneity within grasslands through promoting the formation of grazing lawns (Leonard et al. 2010, Kirkpatrick et al. 2011, 2016). In addition, the juxtaposition of Poa tussocks and short grassland appears to be important in maintaining populations of the endangered Ptunarra Brown Butterfly (Oreixenica ptunarra L.E. Couchman, 1953; Neyland 1993, Bell 1999). Further research is required to precisely determine the appropriate fire regime(s) for maintaining biodiversity values in highland grassland. Examples of grasslands in good condition that have a history of 


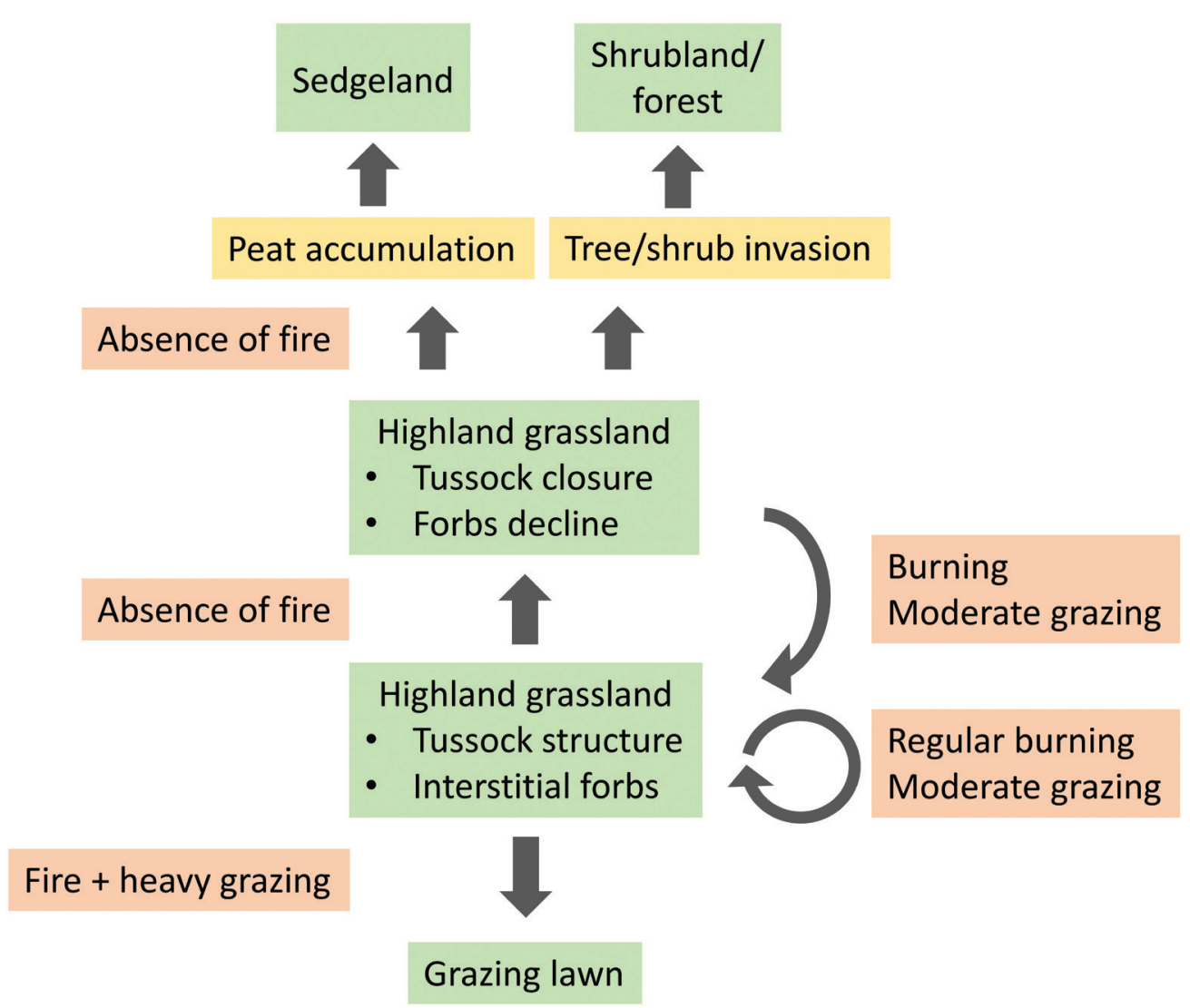

FIG. 2 - Summary of main transitions possible within Tasmanian highland grassland occurring below $1000 \mathrm{~m}$ asl in relation to variation in disturbance regimes. In the prolonged absence of fire grasslands typically exhibit accumulation of grass biomass, with concomitant decline in interstitial species. Absence of fire may also lead to tree/shrub invasion or peat accumulation, and eventual transition to shrubland/forest or sedgeland. Conversely, when fire is followed by heavy grazing, tussock grassland may be converted to lawn. Green boxes represent vegetation states, orange boxes disturbance regimes, and yellow boxes processes leading to vegetation transitions.

"traditional" burning by graziers, which may in turn be based on Indigenous practise, provide circumstantial evidence that such burning regimes are beneficial (Bowman et al. 2013, Wood et al. 2017). Where grasslands are threatened by invasion by fire sensitive shrubs, the vital attributes of the invading species may be able to be used to guide fire management.

In the low productivity environment above $1000 \mathrm{~m}$ asl, slow growth rates and grazing by native animals mean that competitive exclusion of interstitial species by grasses is unlikely to compromise floristic diversity (Gibson \& Kirkpatrick 1989). There would appear to be no ecological need to apply disturbance to these higher altitude grassland, especially as large tracts are still undergoing the long process of recovery from past over-grazing and burning (Bridle et al. 2001, Kirkpatrick \& Bridle 2013). Livestock grazing in particular is antithetical to ecological values in this vegetation.

Active management of highland grassland below $1000 \mathrm{~m}$ utilising periodic low intensity patch burning, in combination with native grazing (which is practically unavoidable in any case), is likely to be conducive to maintaining ecological values in this vegetation. Where such a management regime prevails there is no ecological imperative for cattle grazing. Above $1000 \mathrm{~m}$ active application of disturbance will seldom, if ever, be required. However, given that specific knowledge of optimal disturbance regimes for highland grassland is lacking, management should be accompanied by a well-designed monitoring program and the management strategy regularly reviewed.

\section{ACKNOWLEDGEMENTS}

Many thanks to Jamie Kirkpatrick and Jayne Balmer for comments on an earlier version of this paper. Dr Balmer also provided data on highland grassland extent and reservation.

\section{REFERENCES}

Archibald, S. \& Bond, W.J. 2004: Grazer movements: spatial and temporal responses to burning in a tall-grass African savanna. International Journal of Wildland Fire 13: 377-385.

Balmer, J., Whinam, J., Kelman, J., Kirkpatrick, J.B. \& Lazarus E. 2004: A review of the floristic values of the Tasmanian Wilderness World Heritage Area. Nature Conservation 
Report 2004/3. Department of Primary Industries Water and Environment, Tasmania, Australia: 133 pp.

Bell, P.J. 1999: Ptunarra Brown Butterfly Recovery Plan 19982003. Department of Primary Industries, Water and Environment, Hobart: 20 pp.

Belsky, J.A. 1992: Effects of grazing, competition, disturbance and fire on species composition and diversity in grassland communities. Journal of Vegetation Science 3: 187-200.

Bridle, K.L. \& Kirkpatrick, J.B. 1999: Comparative effects of stock and wild vertebrate herbivore grazing on treeless subalpine vegetation, eastern Central Plateau, Tasmania. Australian Journal of Botany 47: 817-834.

Bridle, K.L. \& Kirkpatrick, J.B. 2001: Impacts of grazing by vertebrate herbivores on the flower stem production of tall alpine herbs, Eastern Central Plateau, Tasmania. Australian Journal of Botany 4: 459-470.

Bridle, K.L., Kirkpatrick, J.B., Cullen, P. \& Shepherd, R.R. 2001: Recovery in Alpine Heath and Grassland Following Burning and Grazing, Eastern Central Plateau, Tasmania, Australia. Arctic, Antarctic, and Alpine Research 33, 348-356

Bond, W.J. 2005: Large parts of the world are brown or black: A different view of the 'Green World' hypothesis. Journal of Vegetation Science 16: 261-266.

Bowman, D.M.J.S., Wood, S.W., Neyland, D., Sanders, G.J. \& Prior, L.D. 2013: Contracting Tasmanian montane grasslands within a forest matrix is consistent with cessation of Aboriginal fire management. Austral Ecology doi:10.1111/aec.12008

Collins, S.L. \& Barber, S.C. 1985 Effects of disturbance on diversity in mixed-grass prairie. Vegetatio 64: 87-94.

Connell, R.M. 1978: Diversity in tropical rainforests and coral reefs. Science 199: 1302-1310.

Cubit, S. 1996: 'Burning back with the snow': traditional approaches to grassland management in Tasmania. Australian Geographical Studies 34: 216-224.

di Folco, M-B \& Kirkpatrick, J.B. 2013 Organic soils provide evidence of spatial variation in human-induced vegetation change following European occupation of Tasmania. Journal of Biogeography 40: 197-205

DPIPWE 2016: TASVEG Vegetation Communities in Tasmania's Reserve System. Available at: http://dpipwe.tas.gov. $\mathrm{au} /$ conservation/development-planning-conservationassessment/planning-tools/tasmanian-reserve-estatespatial-layer. Accessed 8/9/2017.

Ellis, R.C. 1985: The relationships among eucalypt forest, grassland and rainforest in a highland area in north-eastern Tasmania. Australian Journal of Ecology 10: 297-314.

Fensham, R.J. \& Fairfax, R.J. 2006: Can burning restrict eucalypt invasion on grassy balds? Austral Ecology 31: 317-325.

Fensham, R.J. \& Kirkpatrick, J.B. 1989: The conservation of the original vegetation remnants in the Midlands, Tasmania. Papers and Proceedings of the Royal Society of Tasmania 123: 229-246.

Fensham, R.J. \& Kirkpatrick, J.B. 1992: The eucalypt forestgrassland/ grassy woodland boundary in central Tasmania. Australian Journal of Botany 40: 123-138.

Ferguson, A., Kirkpatrick, J.B. \& Pharo, E. 2010: Variability in the incidence and characteristics of animal paths in montane vegetation. Plant Ecology and Diversity 3: 9-17.

Ferguson, A., Pharo, E., Kirkpatrick, J.B. \& Marsden-Smedley, J. 2009: The early effects of fire and grazing on bryophytes and lichens in tussock grassland and hummock sedgeland in north-eastern Tasmania. Australian Journal of Botany 57: 556-561.

Fuhlendorf, S.D. \& Engle D.M. 2004: Application of the fire-grazing interaction to restore a shifting mosaic on tallgrass prairies. Journal of Applied Ecology 41: 604-614.

Fuhlendorf, S.D., Engle, D.M., Kerby, J. \& Hamilton, R. 2008: Pyric herbivory: rewilding landscapes through the recoupling of fire and grazing. Conservation Biology 23: 588-598.
Fuhlendorf, S.D., Townsend , D.E.II, Elmore, R.D. \& Engle D.M. 2010: Pyric herbivory to promote rangeland heterogeneity: evidence from small mammal communities. Rangeland Ecology and Management, 63: 670-678.

Fletcher, M. -S. \& Thomas, I. 2010: The origin and temporal development of an ancient cultural landscape. Journal of Biogeography 37: 2183-2196.

Gibson, N. \& Kirkpatrick, J.B. 1989: Effects of the cessation of grazing on the grasslands and grassy woodlands of the Central Plateau, Tasmania. Australian Journal of Botany 37: 55-63.

Gilfedder L. \& Kirkpatrick, J.B. 1994: Climate, grazing and disturbance, and the population dynamics of Leucochrysum albicans at Ross, Tasmania. Australian Journal of Botany 42: 417-430.

Grubb, P.J. 1986: Problems posed by sparse and patchily distributed species in species-rich plant communities. In Diamond J. \& Case T.J. (eds): Community Ecology. Harper and Row, New York: 207-225.

Henwood, W.D. 2010: Toward a strategy for the conservation and protection of the world's temperate grasslands. Great Plains Research 20: 121-133.

Holz, A., Wood, S.W., Veblen, T.T. \& Bowman, D.M.J.S. 2014: Effects of high-severity fire drove the population collapse of the subalpine Tasmanian endemic conifer Athrotaxis cupressoides. Global Change Biology 21: 445-458.

Jackson, W.D. 1968: Fire, air, water and earth- an elemental ecology of Tasmania. Proceedings of the Ecological Society of Australia 3: 9-16.

Jackson, W.D. 1973: Vegetation of the Central Plateau. In Banks, M. R. (ed): The Lake Country. Royal Society of Tasmania, Hobart: 61-86.

Kitchener, A. \& Harris, S. 2013: From Forest to Fjaeldmark: Descriptions of Tasmania's Vegetation. Edition 2. Department of Primary Industries, Parks, Water and Environment, Hobart. Available at: http://dpipwe.tas.gov.au/conservation/ flora-of-tasmania/from-forest-to-fjaedlmark-descriptionsof-tasmanias-vegetation. Accessed 6/7/2017.

Kirkpatrick J.B. 1983: Treeless plant communities of the Tasmanian High Country. Proceedings of the Ecological Society of Australia 12: 61-77.

Kirkpatrick, J.B. 1991: Grassy vegetation. In Kirkpatrick, J. B., Pharo, E. J., Wells, A., Mendel, L. and Lynch, A. J. J. (eds): Tasmanian Native Bush: A Management Handbook. Tasmanian Environment Centre, Hobart: 92-109.

Kirkpatrick, J.B. 1999: Grassy vegetation and subalpine Eucalypt communities In Reid, J. B., Hill, R. S., Brown, M. J. \& Hovenden, M. J. (eds): Vegetation of Tasmania. Australian Biological Resources Study, Canberra: 265-285.

Kirkpatrick, J.B. 2004: Vegetation change in an urban grassy woodland. Australian Journal of Botany 52: 597-608.

Kirkpatrick, J.B. \& Balmer J. 1991: The vegetation and higher plant flora of the Cradle Mountain-Pencil Pine area, northern Tasmania. In Banks, M.R., Smith, S.J., Orchard, A.E. \& Kantvilas G. (eds): Aspects of Tasmanian Botanya tribute to Winifred Curtis. Royal Society of Tasmania, Hobart: 119-148.

Kirkpatrick, J.B. \& Bridle, K.L. 2013: Natural and cultural histories of fire differ between Tasmanian and mainland Australian alpine vegetation. Australian Journal of Botany 61: 465-474.

Kirkpatrick, J.B. \& Bridle, K.L. 2015: Grazing and the absence of fire promote the dominance of an unpalatable shrub in a patch mosaic cyclic successional system. Australian Journal of Botany 64: 45-50.

Kirkpatrick, J.B. \& Duncan, F. 1987: Tasmanian high altitude grassy vegetation: its distribution, community composition and conservation status. Australian Journal of Ecology 12: 73-86.

Kirkpatrick, J.B., Gilfedder, L. \& Fensham, R. 1988: City Parks and Cemeteries: Tasmania's Remnant Grasslands 
and Woodlands. Tasmanian Conservation Trust, Hobart: $268 \mathrm{pp}$.

Kirkpatrick, J.B., Gilfedder, L., Bridle, K. \& Zacharek, A. 2005: The positive and negative conservation impacts of sheep grazing and other disturbances on the vascular plant species and vegetation of lowland subhumid Tasmania. Ecological Management and Restoration 6: 51-60.

Kirkpatrick, J.B., Marsden-Smedley, J.B. \& Leonard S.W.J. 2011: Influence of grazing and vegetation type on postfire flammability. Journal of Applied Ecology 48, 642-649.

Kirkpatrick, J.B., Marsden-Smedley, J.B. \& Leonard S.W.J. 2016: Influence of grazing and vegetation type on post-fire floristic and lifeform composition in Tasmania, Australia. Plant Ecology 217: 57-69.

Land Tasmania, 2007: TAS LIST Tasmania $25 \mathrm{~m}$ Digital Elevation Model, GDA94 / MGA zone 55, Department of Primary Industries, Parks, Water and Environment, Hobart.

Leigh, J.H. \& Holgate, M.D. 1978: Effects of pasture availability on the composition and quality of the diet selected by sheep grazing native, degenerate and improved pastures in the Upper Shoalhaven Valley, New South Wales. Australian Journal of Experimental Agriculture and Animal Husbandry 18: 381-390.

Leonard, S.W.J. 2009: Predicting sustained fire spread in Tasmanian native grasslands. Environmental Management 44: 430-440.

Leonard, S.W.J. \& Kirkpatrick, J.B. 2004: Effects of grazing management and environmental factors on native grassland and grassy woodland, Northern Midlands, Tasmania. Australian Journal of Botany 42: 529-542.

Leonard, S.W.J., Kirkpatrick, J.B. \& Marsden-Smedley, J.B. 2010 Variation between grassland structural types in the effects of vertebrate grazing on fire potential. Journal of Applied Ecology 47, 876-883.

Lunt, I.D. 1991: Management of remnant lowland grasslands and grassy woodlands for nature conservation: a review. The Victorian Naturalist 1083, 57-66.

Lunt, I.D. 1997a: Effects of long-term vegetation management on remnant grassy forests and anthropogenic native grasslands in south-eastern Australia. Biological Conservation 81: 287-297.

Lunt, I.D. 1997b: A multivariate growth-form analysis of grassland and forest forbs in south-eastern Australia. Australian Journal of Botany 45: 691-705.

Lunt, I.D. 1997c: The distribution and environmental relationships of native grasslands on the Lowland Gippsland Plain, Victoria: an historical study. Australian Geographical Studies 35: 140-152.

McIntyre, S. \& Lavorel, S. 1994: How environmental and disturbance factors influence species composition in temperate Australian grasslands. Journal of Vegetation Science 5: 373-384.

McNaughton, S.J. 1984 Grazing lawns: animals in herds, plant form and coevolution. The American Naturalist 1246: 863-886.
Milchunas, D.G., Sala, O.E. \& Lauenroth, W.K. 1988: A generalized model of the effects of grazing by large herbivores on grassland community structure. The American Naturalist 132: 87-106.

Moss, P.T., Thomas, I. \& MacPhail, M. 2007: Late Holocene vegetation and environments of the Mersey Valley, Tasmania. Australian Journal Botany 55: 74-82.

Murphy, B.P \& Bowman, D.M.J.S. 2007: The interdependence of fire, grass, kangaroos and Australian Aborigines: a case study from central Arnhem Land, northern Australia. Journal of Biogeography 34: 237-250.

Neyland, M.G. 1993: The ecology and conservation of the ptunarra brown butterfly Oreixenica ptunarra Lepidotera; Nymphalidae; Satyrinae in Tasmania, Australia. Papers and Proceedings of the Royal Society of Tasmania 127: 43-48.

Noy-Meir, I., Gutman, M. \& Kaplan, Y. 1989: Responses of Mediterranean grassland to grazing and protection. Journal of Ecology 77: 290-310.

Parry, J., Kirkpatrick, J.B. \& Marsden-Smedley, J., 2016: Explaining the distribution, structure and species composition of snow patch vegetation in Tasmania, Australia. Australian Journal of Botany 64, 484-491.

Schnoor, T., Bruun, H.H. \& Olsson, P.A. 2015: Soil disturbance as a grassland restoration measure - effects on plant species composition and plant functional traits. PLoS One, 10: e0123698.

Shepherd, R.R. 1973: Land use on the Central Plateau with special reference to the grazing land. In Banks, M. R. (ed) The Lake Country. Royal Society of Tasmania, Hobart: 61-86.

Stuwe, J. \& Parsons, R.F. 1977: Themeda australis grasslands on the Basalt Plains, Victoria: Floristics and management effects. Australian Journal of Ecology 2: 467-476.

Styger, J., Kirkpatrick, J.B., Marsden-Smedley, J.B. \& Leonard, S.W.J. 2011: Fire incidence, but not fire size, affects macropod densities. Austral Ecology 36: 679-686.

Tengia, B., Taylor, M. \& Kirkpatrick, J. 2016: Conservation tool or threatening process? management implications of interactions of cattle with vegetation and land at the Vale of Belvoir reserve. Ecological Management and Restoration 17: $147-151$

Tremont, R.M. \& McIntyre, S. 1994: Natural grassy vegetation and native forbs in temperate Australia: structure, dynamics and life histories. Australian Journal of Botany 42: 641-658.

TVMMP 2013: TASVEG 3.0, Digital statewide 1:25,000 scale vegetation map of Tasmania, Tasmanian Vegetation Monitoring and Mapping Program, Department of Primary Industries, Parks, Water and Environment, Hobart.

Wood, S.W., Ward, C. \& Bowman, D.M.J.S 2017: Substrate controls growth rates of the woody pioneer Leptospermum lanigerum colonizing montane grasslands in northern Tasmania. Austral Ecology 42: 9-19.

(Accepted 3 October 2017) 


\section{APPENDIX 1 - Systematic review of literature concerning fire and grazing in Tasmanian highland grasslands, published since 1999}

Here we summarise the results of a systematic review of papers concerning fire and/or grazing in Tasmanian highland grasslands published in peer reviewed journals since the publication of Kirkpatrick (1999) (the last major review covering this vegetation). Relevant papers were identified by searching the Scopus and Web of Science literature databases using various combinations of the search terms "fire", "grazing", "Tasmania", "grassland”, "grassy”, "highland", "montane" and "alpine". Relevant papers were subjectively selected from search results, on the basis that they were focused on a) Tasmanian highland grasslands (alone, or in combination with other vegetation types), and b) fire and/or grazing. This process produced a list of 14 papers (see reference list above for full references). Six deal with effects of fire and grazing on flora and/or vegetation, three on grazing effects alone and two on fire effects alone. Two examine the process of woody invasion of grassland due to reduction in fire frequency, with one examining fire behaviour.

A number of "eras" or bodies of research are reflected in the results. Bridle \& Kirkpatrick (1999, 2001) and Bridle et al. 2001 describe a series of studies of examining grazing effects and vegetation recovery following fire and over-grazing on the Central Plateau. Papers by Ferguson et al. (2009), Leonard (2009), Leonard et al. (2010) and Kirkpatrick et al. $(2011,2016)$ stem from a study of fire/ grazing interactions in highland (and lowland) grassland, while Bowman et al. (2013) and Wood et al. (2017) examine landscape-scale vegetation change due to changed fire regimes. Discussion of the findings of these studies, and their implications for highland grassland management are included in the main body of the current paper.
Results of systematic review of papers concerning fire and/or grazing in Tasmanian highland grasslands published in peer reviewed journals since 1999

\begin{tabular}{ll}
\hline Author(s) \& year & \multicolumn{1}{c}{ Topic } \\
\hline Leonard (2009) & Fire behaviour \\
Holz et al. (2015) & Fire effects, fire history \\
Kirkpatrick \& Bridle (2013) & Fire effects, fire history \\
Bridle et al. (2001) & Fire/grazing effects \\
Ferguson et al. (2009) & $\begin{array}{l}\text { Fire/grazing effects (on } \\
\text { bryophytes) }\end{array}$ \\
Kirkpatrick \& Bridle (2016) & Fire/grazing effects \\
Kirkpatrick et al. (2011) & Fire/grazing effects \\
Kirkpatrick et al. (2016) & Fire/grazing effects \\
Leonard et al. (2010) & Fire/grazing effects \\
Bridle \& Kirkpatrick (1999) & Grazing effects \\
Bridle \& Kirkpatrick (2001) & Grazing effects \\
Tengia et al. (2016) & Grazing effects \\
Bowman et al. (2013) & $\begin{array}{l}\text { Vegetation change in relation } \\
\text { to changed fire regimes } \\
\text { Wood } \text { et al. (2017) }\end{array}$ \\
\hline & $\begin{array}{l}\text { Vegetation change in relation } \\
\text { to changed fire regimes }\end{array}$ \\
\hline
\end{tabular}

